\title{
Analysis of mutations in $G B A$ gene in Ukrainian patients with Gaucher disease
}

\author{
N. V. Olkhovych ${ }^{1}$, A. M. Nedoboy ${ }^{2}$, N. O. Pichkur ${ }^{2}$, N. H. Gorovenko ${ }^{1}$ \\ ${ }^{1}$ State Institute of Genetic and Regenerative Medicine, NAMS of Ukraine \\ 67, Vyshhorodska Str., Kyiv, Ukraine, 04114 \\ ${ }^{2}$ National Children's Specialized Hospital Okhmatdyt, Ministry of Health of Ukraine \\ 28/1, Chornovola Str., Kyiv, Ukraine, 01135 \\ nolhovich@gmail.com
}

\begin{abstract}
Gaucher disease (MIM 230800) is the most common storage disorder, caused by hereditary deficiency of the lysosomal enzyme of glucocerebrosidase (EC 3.2.1.45). Human glucocerebrosidase gene $(G B A)$ is mapped in locus lq21, it is $7.5 \mathrm{~kb}$ long and consists of 11 exons. According to the data of the largest human gene mutation databases, there are over 300 currently described pathogenic variants of $G B A$ gene, most of them are related to the development of Gaucher disease. Aim. To identify rearrangements in the $G B A$ gene which conditioned the development of Gaucher disease in Ukrainian patients, to compare their spectrum with the variants in patients from Slavonic and other European countries and to evaluate genotype-phenotype associations for this disease. Methods. The Sanger's method of direct automated sequencing using ABI 3130 analyzer (Applied Biosystems). Results. The application of different molecular and genetic approaches, including direct sequencing of gene sequence, allowed us to identify $96.8 \%$ of mutant alleles in Ukrainian patients with Gaucher disease. Also six new and previously not described rearrangements of the GBA gene sequence were identified. Conclusion. The comparison of genotypes with clinical form of the disease, identified in patients, demonstrated that our results do not contradict the current recognized genotype-phenotype correlations, which allow predicting the type and clinical course of the Gaucher disease to some degree.
\end{abstract}

Ke y w o r d s: Gaucher disease, $G B A$ gene.

\section{Introduction}

Gaucher disease (MIM 230800) is the most common storage disorder, caused by hereditary deficiency of the lysosomal enzyme of glucocerebrosidase (EC 3.2.1.45) [1]. In clinical terms, Gaucher disease is divided into three types depending on the presence and rate of neurological manifestation progress [2]. Type I Gaucher disease (non-neuronopathic) is the most common form, characterized by the absence of neurological symptoms. The main

(C) 2017 N. V. Olkhovych et al.; Published by the Institute of Molecular Biology and Genetics, NAS of Ukraine on behalf of Biopolymers and Cell. This is an Open Access article distributed under the terms of the Creative Commons Attribution License (http://creativecommons.org/licenses/by/4.0/), which permits unrestricted reuse, distribution, and reproduction in any medium, provided the original work is properly cited 
clinical features of this type of disorder are hepatosplenomegaly, pancytopenia and bone system abnormalities in rather a wide spectrum of severity - from asymptomatic cases to early and short manifestation with fatal outcome during the first years of life. Type II Gaucher disease (acute neuronopathic) is the rarest form, the main symptom of which, in addition to organomegaly, is early and rapid development of severe neurological damage, fatality in utero or during infancy. Type III Gaucher disease (chronic neuronopathic) is a transient form which covers all patients with organomegaly and any neurological signs, manifested after the second year of life.

The human glucocerebrosidase gene $(G B A)$ is mapped in locus lq21, it is $7.5 \mathrm{~kb}$ long and consists of 11 exons. The pseudogene GBAP, remarkable for almost $96 \%$ homology to the functional gene, is located $16 \mathrm{~kb}$ downstream [3]. The region, surrounding the $G B A$ gene, contains seven other genes and pseudogenes (MTXI, MTX1P1, THBS3, MUC1, PROPIN1, COTE1, $C L K 2$ ), which may be involved in the process of forming different fusion or recombinant variants with the $G B A$ gene during the crossing-over of this chromosome region [4].

According to the data of the largest human gene mutation databases (dbSNP, 1000 Genomes, HGMD), there are over 300 currently described pathogenic variants of the $G B A$ gene, most of them are related to the development of Gaucher disease. As for other pathological variants, there are some large described insertions/deletions, including the deletion of the whole gene [5], as well as a considerable number of complex alleles (recalleles), which were formed due to the crossing-over between the functional gene $G B A$ and surrounding genetic structures, most frequently the pseudogene $G B A P$.

Similar to most hereditary human diseases, Gaucher disease is remarkable for considerable variability of the frequencies of pathological variants of the gene in different populations. For instance, the population of Ashkenazi Jews is notable for a very high frequency of several variants - p.N409S, p.L483P, c.84dupG, IVS2(+1)A, RecNciI and RecTL, which together comprise about $90 \%$ of all mutant alleles, with a single replacement p.N409S remarkable for over $70 \%$ mutant alleles [6]. At the same time, these pathological variants in non-Jewish patients account for the total of no more than $60 \%$ of mutant alleles, and the frequency of replacement p.N409S is in the range of 10-50\% depending on the population [5].

There have been studies of the spectrum of pathological variants of the $G B A$ gene in patients, suffering from Gaucher disease, in many European countries [7-15]. This information is of great relevance for understanding the origin and distribution of the pathological variants of this disease as well as for the evaluation of genotype-phenotype correlations among patients.

The aim of our work was to identify pathological variants in the $G B A$ gene which caused the development of Gaucher disease in Ukrainian patients, to compare their spectrum with the variants in the patients from Slavonic and other European countries and to evaluate the genotype-phenotype associations for this disease.

\section{Materials and Methods}

\section{Patients}

The genotype was analyzed in 63 patients of age from 6 months to 65 years from different 
regions of Ukraine, who were diagnosed with Gaucher disease during the period from 2001 to 2016 , based on the complex of clinical (anemia, thrombocytopenia, hepatosplenomegaly), morphological (Gaucher-like cells in the bone marrow biopsy sample) and biochemical (glucocerebrosidase activity deficiency in blood leukocytes) data. As the Center of Orphan Diseases of NCSH OKHMATDYT of the Ministry of Health of Ukraine is the only institution in Ukraine to conduct biochemical and molecular-genetic testing of Gaucher patients, the group of patients, examined by us, may be deemed as the representative group of Ukrainian population. The control group to analyze the pathogenicity of new mutations was formed from the blood samples of 50 volunteer donors aged from 18 to 60 years without any clinical signs of lysosomal pathology. All patients (patients' parents) and volunteer donors gave their informed consent to the use of their biomaterial for the study. The work has been approved by the Ethics Committee of SI IGRM NAMS of Ukraine.

\section{Screening of major mutations}

Genomic DNA was isolated from peripheral blood samples, obtained from EDTA, using commercial sets NucleoSpin ${ }^{\circledR}$ Blood (Macherey-Nagel, Germany) according to the manufacturer's instructions. Missense replacements p.N409S and p.L483P were determined by the method of nested PCR and subsequent RFLP-analysis as described previously [16]. The identification of the mentioned mutations was conducted using restriction endonucleases Xho1 and Msp1 (MBI Fermentas).

\section{Sequencing of GBA gene}

Due to the availability of highly homologous pseudogene $G B A P$, the exon amplification of the $G B A$ gene was conducted using the technology of nested PCR, the first stage of which involved the primers, specific for the sequence of the functional gene (GenBank Accession No. AH006907.2). The sequence of primers, which were used for each stage of nested PCR, is presented in Table 1. The design of primers was independently elaborated using Primer3 software, web-version 4.0.0 (http://bioinfo.ut.ee/primer3/), the synthesis of primers was ordered in Apply Biosystems (USA).

The first stage of nested PCR envisaged obtaining PCR products of 1-4 exons using primers $1 \mathrm{~F}$ and $4 \mathrm{R}$ (product $1873 \mathrm{bp}$ ), 4-8 exons using primers $4 \mathrm{~F}$ and $8 \mathrm{R}$ (product $3777 \mathrm{bp}$ ) and $8-11$ exons using primers $8 \mathrm{~F}$ and 11BR (product $2267 \mathrm{bp}$ ). At the second stage of nested PCR the fragments of the coding part of the $G B A$ gene exons were obtained along with 5'- and 3'-non-translating regions and intron/exon boundary, using exon-specific primers (Table 1). The purification of PCR products was conducted using the commercial kits NucleoSpin ${ }^{\circledR}$ Gel and PCR Clean-up (Macherey-Nagel, Germany) according to the manufacturer's instructions.

The identification of sequence variants of the $G B A$ gene was conducted by the method of Sanger's direct automatic sequencing using ABI Prism 3130 (Applied Biosystems, USA) and BigDye Terminator sequencing kit (Applied Biosystems, USA) according to the manufacturer's protocol. All the identified rearrangements were confirmed by sequencing using both forward- and reverse-primers. The 
Table 1. The design of primers for the $G B A$ gene analysis

\begin{tabular}{|c|c|c|c|c|}
\hline $\begin{array}{l}\text { రే } \\
\text { 爻 }\end{array}$ & $\begin{array}{l}\text { Type } \\
\text { of } \\
\text { primer }\end{array}$ & $\begin{array}{l}\text { The sequence of primer } \\
\qquad\left(5^{\prime}-3^{\prime}\right)\end{array}$ & $\begin{array}{c}\mathrm{Tm} \\
{ }^{\circ} \mathrm{C}\end{array}$ & $\begin{array}{l}\text { The } \\
\text { product } \\
\text { size, bp }\end{array}$ \\
\hline \multirow{2}{*}{1} & $\mathrm{~F}$ & aacagatgagaggaagccaat* & 57.9 & \multirow{2}{*}{509} \\
\hline & $\mathrm{R}$ & tctgtgccttgctcaaagag & 59.3 & \\
\hline \multirow{2}{*}{2} & $\mathrm{~F}$ & gtgggccttgtcctaatgaa & 60.3 & \multirow{2}{*}{372} \\
\hline & $\mathrm{R}$ & aacaaaatcctcaccccaaa & 62.9 & \\
\hline \multirow{2}{*}{3} & $\mathrm{~F}$ & ctcggcctcctaaagtgcta & 59.6 & \multirow{2}{*}{552} \\
\hline & $\mathrm{R}$ & gtagcaggcetgaggacatc & 59.8 & \\
\hline \multirow{2}{*}{4} & $\mathrm{~F}$ & taaccattacacccetcacc* & 57.2 & \multirow{2}{*}{507} \\
\hline & $\mathrm{R}$ & caccactgcactcetgtctc* & 59.4 & \\
\hline \multirow{2}{*}{5} & $\mathrm{~F}$ & aacccaggagcccaagttc & 61.4 & \multirow{2}{*}{494} \\
\hline & $\mathrm{R}$ & gttcagccattagcctccac & 69.7 & \\
\hline \multirow{2}{*}{6} & $\mathrm{~F}$ & gacattttgtcccetgctgt & 60.0 & \multirow{2}{*}{533} \\
\hline & $\mathrm{R}$ & ctgatggagtgggcaagatt & 60.0 & \\
\hline \multirow{2}{*}{7} & $\mathrm{~F}$ & aggctgttctcgaactcctg* & 59.6 & \multirow{2}{*}{598} \\
\hline & $\mathrm{R}$ & aggggaatggtgctctagga & 61.0 & \\
\hline \multirow{2}{*}{8} & $\mathrm{~F}$ & aaaaatctccccaaacctctc* & 58.6 & \multirow{2}{*}{585} \\
\hline & $\mathrm{R}$ & atcatggttccccagagttg & 59.8 & \\
\hline \multirow{2}{*}{9} & $\mathrm{~F}$ & cccacatgtgaccettacct & 59.7 & \multirow{2}{*}{354} \\
\hline & $\mathrm{R}$ & gttccaccctgaacaccttc & 59.4 & \\
\hline \multirow{2}{*}{10} & $\mathrm{~F}$ & agcctctgcaggagttatgg & 59.5 & \multirow{2}{*}{477} \\
\hline & $\mathrm{R}$ & agagtgtgatcctgccaagg & 60.3 & \\
\hline \multirow{2}{*}{$11 \mathrm{a}$} & $\mathrm{F}$ & gctctgctgttgtggtcgt & 60.0 & \multirow{2}{*}{498} \\
\hline & $\mathrm{R}$ & gtttccaaagcaagcagcac & 61.0 & \\
\hline \multirow{2}{*}{$11 b$} & $\mathrm{~F}$ & tgactaaagagggcacagca & 59.6 & \multirow{2}{*}{592} \\
\hline & $\mathrm{R}$ & gtcctcacgctcccaagact & 61.8 & \\
\hline
\end{tabular}

* Primers specific to the sequence of the functional $G B A$ gene

analysis of sequencing results was made using programs Chromas and BLAST (http://www. ncbi.nlm.nih.gov/blast). The electronic databases of known pathogenic variants - dbSNP, 1000 Genomes, HGMD - were used to characterize the identified rearrangements. The analysis of pathogenicity of new variants was made using programs PolyPhen2 (http:/genet- ics.bwh.harvard.edu/pph2), SNPs3D (http:// www.snps3d.org) and Provean (http://provean. jcvi.org/index.php). The description of rearrangements in the $G B A$ gene was based on the nomenclature, recommended by the Human Genome Variation Society (HGVS version $15.11,2016)$, with the consideration of the first 39 amino acids of preprotein $[17,18]$. To facilitate the comparison of the obtained results against the previous publications, the first mention of the rearrangement was made with the indication of the traditional name in brackets, without the consideration of 39 amino acids of preprotein.

\section{Results}

Our examination involved 63 patients from 63 families with confirmed diagnosis of Gaucher disease from all the regions of Ukraine, including 57 patients, clinically classified as type I Gaucher disease (type I GD), 2 patients with type II Gaucher disease (type II GD), and 4 patients with type III Gaucher disease (type III GD). The severity degree of the clinical course was determined according to the severity index (SSI), suggested by Zimran et al. [19]. Table 2 presents the summarized clinical and molecular-genetic characteristics of the patients, examined by us. Three families had two sick siblings each, but only one sibling from each family was used in calculations of allele frequencies.

A total of 124 out of 126 (98.4\%) mutant alleles of the $G B A$ gene were identified. If two previously described rearrangements were identified in a patient, it was assumed that they were in trans-position, which was confirmed by the analysis of parents, if available. The biological material of parents was unavailable 
Table 2. The genotype and phenotype of Gaucher patients from Ukraine

\begin{tabular}{|c|c|c|c|c|c|}
\hline \multirow{2}{*}{$\mathrm{N}$} & \multirow{2}{*}{ 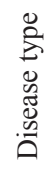 } & \multirow{2}{*}{ 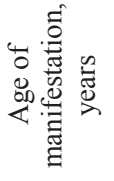 } & \multicolumn{2}{|c|}{ Genotype } & \multirow{2}{*}{$\overrightarrow{\tilde{n}}$} \\
\hline & & & 1 allele & 2 allele & \\
\hline 1 & I & 3 & N409S & RecNciI & 7 \\
\hline 2 & I & 3 & del55 & L483P+RecG & 6 \\
\hline 3 & I & 9 & N409S & N409S & 6 \\
\hline 4 & I & 55 & N409S & R159W & 6 \\
\hline 5 & I & 1 & S390I & L483P & 7 \\
\hline 6 & I & 3 & N409S & N409S & 6 \\
\hline 7 & I & 3 & N409S & $\mathrm{RecC} 2$ & 8 \\
\hline 8 & I & 3 & $?$ & $\operatorname{Rec} \mathrm{G}$ & 7 \\
\hline 9 & I & 10 & N409S & L483P & 7 \\
\hline 10 & I & 4 & R87W & $\mathrm{RecC} 2$ & 7 \\
\hline 11 & I & 3 & $\mathrm{R} 202 *$ & $\mathrm{~L} 483 \mathrm{P}+\mathrm{RecG}$ & 6 \\
\hline 12 & I & 18 & N409S & N409S & 6 \\
\hline 13 & I & 0,5 & L483P & RecNciI & 8 \\
\hline 14 & I & 19 & N409S & c1324_1326delATT & 6 \\
\hline 15 & I & 45 & N409S & N409S & 4 \\
\hline 16 & I & 5 & $\mathrm{R} 502 \mathrm{C}$ & L483P & 11 \\
\hline 17 & I & 3 & $?$ & $\operatorname{Rec} \mathrm{G}$ & 8 \\
\hline 18 & I & 6 & N409S & $\mathrm{L} 483 \mathrm{P}+\mathrm{RecG}$ & 6 \\
\hline 19 & I & 7 & $\mathrm{R} 87 \mathrm{~W}$ & c901delC & 4 \\
\hline 20 & I & 3 & N409S & W223R & 9 \\
\hline 21 & I & 40 & F167L & Q453R & 7 \\
\hline 22 & I & 15 & N409S & R159W & 8 \\
\hline 23 & I & 1 & $\mathrm{I} 200 \mathrm{~S}$ & L483P & 5 \\
\hline 24 & I & 5 & N409S & $\mathrm{R} 202 *$ & 6 \\
\hline 25 & I & 3 & N409S & L327P & 7 \\
\hline 26 & I & 20 & N409S & P430A & 8 \\
\hline 27 & I & 2 & N409S & L483P & 7 \\
\hline 28 & I & 0,5 & $\mathrm{R} 202 *$ & G241R & 8 \\
\hline 29 & I & 25 & N409S & L483P & 6 \\
\hline 30 & I & 16 & N409S & RecC 2 & 6 \\
\hline 31 & II & 0,5 & $84 \mathrm{GG}$ & P430A & 26 \\
\hline 32 & I & 12 & N409S & $\mathrm{R} 535 \mathrm{C}$ & 7 \\
\hline
\end{tabular}

\begin{tabular}{|c|c|c|c|c|c|}
\hline \multirow{2}{*}{$\mathrm{N}$} & \multirow{2}{*}{ 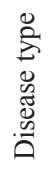 } & \multirow{2}{*}{ 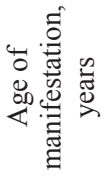 } & \multicolumn{2}{|c|}{ Genotype } & \multirow{2}{*}{$\overrightarrow{\tilde{\sigma}}$} \\
\hline & & & 1 allele & 2 allele & \\
\hline 33 & I & 21 & N409S & R159W & 5 \\
\hline 34 & I & 15 & N409S & L483P & 11 \\
\hline 35 & I & 20 & N409S & L483P & 7 \\
\hline 36 & I & 3 & G416S & G416S & 6 \\
\hline 37 & I & 5 & N409S & L483P & 6 \\
\hline 38 & I & 2 & N409S & $\operatorname{RecC} 2$ & 5 \\
\hline 39 & I & 6 & N409S & L483P & 6 \\
\hline 40 & I & 15 & N409S & R159W & 5 \\
\hline 41 & I & 10 & N409S & L483P & 7 \\
\hline 42 & I & 3 & N409S & $\mathrm{P} 217 \mathrm{~S}$ & 8 \\
\hline 43 & I & 15 & N409S & N131I & 6 \\
\hline 44 & I & 3 & N409S & L483P & 5 \\
\hline 45 & I & 45 & N409S & L483P & 5 \\
\hline 46 & I & 5 & N409S & RecNciI & 8 \\
\hline 47 & I & 5 & N409S & RecNciI & 6 \\
\hline 48 & I & 15 & N409S & $\mathrm{RecC}$ & 6 \\
\hline 49 & III & 5 & $\begin{array}{l}\text { R159W+ } \\
\text { G241R }\end{array}$ & D448H & 26 \\
\hline 50 & III & 1 & G416S & c999G-A & 37 \\
\hline 51 & I & 0,5 & V414L & $\mathrm{RecC}$ & 13 \\
\hline 52 & I & 6 & N409S & L483P & 6 \\
\hline 53 & I & 6 & N409S & L483P & 13 \\
\hline 54 & III & 3 & $\mathrm{~N} 277 \mathrm{~S}$ & Y244* & 25 \\
\hline 55 & I & 12 & N409S & A423D & 8 \\
\hline 56 & I & 42 & L483P & $\mathrm{RecC} 2$ & 4 \\
\hline 57 & III & 0,5 & G416S & c203dupC & 26 \\
\hline 58 & I & 5 & N409S & N409S & 6 \\
\hline 59 & I & 5 & N409S & R159W & 6 \\
\hline 60 & I & 4 & N409S & $\mathrm{R} 202 *$ & 6 \\
\hline 61 & II & 0,5 & G241R & A423D & 26 \\
\hline 62 & I & 5 & G416S & G416S & 8 \\
\hline 63 & I & 4 & N409S & L483P & 7 \\
\hline
\end{tabular}


for patients No. 4, 15, 21, 45 and 56. New variants were identified while obtaining the identical results of sequencing two independent PCR products and confirmed by the analysis of parents.

In total, 32 different pathogenic variants of the $G B A$ gene were identified. As expected, the most common variant was a single nucleotide replacement in exon 9 p.N409S (N370S) - it was found in 45 out of 124 alleles, which amounted to $36.3 \%$. Five patients had this replacement in homozygous state, and 35 - in heterozygous state.

The second most frequent pathogenic variant of the $G B A$ gene was the missense replacement in exon 10 p.L483P (L444P), it was identified as an individual mutation in 18 alleles out of 124 , which amounted to $14.5 \%$. This replacement was not identified in homozygous state in any case. Three other patients had the p.L483P replacement as part of the most common recombinant allele RecNciI, which is the result of the conversion of a fragment of exon 10 of the functional gene and a pseudogene, and which, in addition to replacement p.L483p, also carries two replacements p.A495P (A456P) and p.V499V (V460V) in cis-position, remarkable for the pseudogene sequence. Additionally, it was established that three patients had replacement p.L483P in cisposition with single nucleotide replacements c. ${ }^{*} 92 \mathrm{G}>\mathrm{A}$ and c. ${ }^{*} 102 \mathrm{~T}>\mathrm{C}$, localized in 3 '-nontranslating region (3'UTR) of the $G B A$ gene. These replacements were also notable for the sequence of pseudogene $G B A P$, thus, there is high probability of these patients to have the recombination between a gene and a pseudogene in the site of intron $10-3$ 'UTR, described as RecG allele [5].
The third most frequent variant (6 out of 124 alleles, $4.8 \%$ ) was found to be a missense replacement in exon 5 p.R159W (R120W), which was identified in six patients: in five - in the compound with p.N409S, and in one patient with type III GD in the compound with a missense replacement in exon 6 p.G241R (G202R). The same number of alleles (6 out of $124,4.8 \%$ ) had a missense replacement in exon 9 p.G416S (G377S), which was identified in four patients: two had it in a homozygous state and two - in the compound with another single nucleotide rearrangement.

Additionally, our studies identified previously described missense replacement p.G241R (G202R) - in three alleles (2.4\%), missense replacements p.R87W (R48W) and p.A423D (A384D) - in two alleles each (1.6\% each), missense replacements p.I200S (I161S), p.P217S (P178S), p.N227S (N188S), p.W223R (W184R), p.L327P (L288P), p.Q453R (Q414R), p.D448H (D409H), p.V414L (V375L), p.R502C (R463C) and p.R535C (R496C) - in one allele each $(0.8 \%$ each). It was established that four alleles (3.2\%) had a nonsense replacement in exon 6 p.R202* (R163*) in a heterozygous state. Other single nucleotide rearrangements, identified in single cases, were the duplications of c.84dupG and c.203dupC, as well as a threenucleotide deletion without any shift in the reading frame c.1324_1326delATT and deletion c.1265_1319del55 in exon 9.

It was observed that there was rather a high prevalence of recombinant alleles among our examined patients with the involvement of the functional gene $G B A$ and pseudogene $G B A P$. For instance, in addition to the abovementioned seven patients with alleles RecNciI and RecG, five patients with a complex of six replace- 
ments of pseudogene origin in cis-position in exon 6 (p.W223R, p.N227R, p.V230G, p.S235P, p.G241R, p.F252I) were identified, which may correspond to the described recombinant allele RecC with the conversion of a site between intron 5 and exon 7 (g.4179_5042con) [5]. It was found that two more patients had cis-position of the abovementioned six replacements of pseudogene origin in exon 6 and replacements p.R159W in exon 5. This combination may correspond to the described recombinant allele RecC5a with the conversion of a site between intron 4 and exon 6 (g.3941 4430con) [5]. Furthermore, two patients had the single nucleotide replacements c. ${ }^{* 92} \mathrm{G}>\mathrm{A}$ and c. ${ }^{*} 102 \mathrm{~T}>\mathrm{C}$, localized in 3'-nontranslating region (3'UTR) of the $G B A$ gene. These replacements were also notable for the sequence of pseudogene $G B A P$, thus, there is high probability of these patients to have the recombination between a gene and a pseudogene in the site of intron $11-3$ 'UTR [5]. Therefore, the total frequency of recombinant alleles was $12.9 \%$. Notably, the final confirmation of the availability and localizations of recombinant alleles requires additional studies.

Six pathogenic rearrangements, which have not been previously described, are identified in the $G B A$ gene - four missense replacements:
p.N131I in exon 4, p.F167L in exon 5, p.S390I in exon 8 and p.P430A in exon 9; a nonsense replacement p.Y244* in exon 6 and a single nucleotide deletion c.901delC in exon 7 . The pathogenicity of the identified rearrangements was confirmed in silico using programs PolyPhen2, SNPs3D and Provean (Table 3). None of the mentioned rearrangements was found in the database of 1000 Genomes or in 50 samples of donor blood, examined by us. The paternal analysis demonstrated that replacements p.S390I and p.Y244* were inherited by probands from fathers, whereas rearrangements p.N131I and c.901delC were inherited by probands from mothers. The paternal analysis of rearrangements p.F167L and p.P430A was not conducted due to the unavailability of the parental biological material of the probands.

Unfortunately, genotypes of two patients (patients 8 and 17) are yet to be determined completely. It was identified that patient 8 had a previously non-described missense replacement p.P94S in exon 3 of the $G B A$ gene, which was evaluated as a polymorphic variant during the pathogenicity check (Table 4). However, we have no possibility to detect the second pathogenic alleles in these patients due to a lack of material.

Table 3. The analysis of pathogenicity of new mutations in the $G B A$ gene

\begin{tabular}{|c|c|c|c|c|c|}
\hline \multicolumn{2}{|c|}{ Rearrangements } & \multicolumn{3}{|c|}{ Score } & \multirow{2}{*}{ Conclusion } \\
\hline protein & cDNA & PolyPhen $2^{1}$ & $\mathrm{SNPs}^{2} \mathrm{D}^{2}$ & Provean $^{3}$ & \\
\hline p.P94S & c. $402 \mathrm{C}>\mathrm{T}$ & 0.001 & 1.86 & -0.555 & benign \\
\hline p.N131I & c. $514 \mathrm{~A}>\mathrm{T}$ & 1.000 & -1.07 & -7.134 & deleterious \\
\hline p.F167L & c. $621 \mathrm{~T}>\mathrm{C}$ & 0.990 & -2.36 & -5.350 & deleterious \\
\hline p.S390I & c. $1291 \mathrm{G}>\mathrm{T}$ & 0.997 & 0.21 & -2.800 & deleterious \\
\hline p.P430A & c. $1410 \mathrm{C}>\mathrm{G}$ & 1.000 & -2.82 & -7.516 & deleterious \\
\hline
\end{tabular}

${ }^{1} \Delta$ PSIC $\leq 0,5$ - benign; ${ }^{2}$ SVM score $>0,5-$ benign; ${ }^{3}$ Provean score $>-2,5-$ benign. 
Table 4. The genotype frequencies in Gaucher patients from Ukraine

\begin{tabular}{|c|c|c|}
\hline 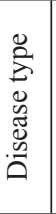 & Genotype & $\begin{array}{c}\text { Number of } \\
\text { genotypes/ } \\
\text { total number } \\
\text { of investigated } \\
\text { patients } \\
\text { (frequences) }\end{array}$ \\
\hline A & $\begin{array}{l}\text { p.N409S/p.N409S } \\
\text { p.N409S/p.L483P } \\
\text { p.N409S/p.R159W } \\
\text { p.N409S/RecNciI } \\
\text { p.N409S/RecC5a } \\
\text { p.N409S/p.R202* } \\
\text { p.N409S/p.A423D } \\
\text { p.N409S/c.1324_1326delATT } \\
\text { p.N409S/p.L327P } \\
\text { p.N409S/p.N131I } \\
\text { p.N409S/p.P217S } \\
\text { p.N409S/p.W223R } \\
\text { p.N409S/p.P430A } \\
\text { p.N409S/p.R535C } \\
\text { p.N409S/RecC } \\
\text { p.N409S/p.L483P+RecG } \\
\text { p.L483P/p.I200S } \\
\text { p.L483P/RecC5a }\end{array}$ & $\begin{array}{l}5 / 63(7.9 \%) \\
13 / 63(20.6 \%) \\
5 / 63(7.9 \%) \\
3 / 63(4.8 \%) \\
3 / 63(4.8 \%) \\
2 / 63(3.2 \%) \\
1 / 63(1.6 \%) \\
1 / 63(1.6 \%) \\
1 / 63(1.6 \%) \\
1 / 63(1.6 \%) \\
1 / 63(1.6 \%) \\
1 / 63(1.6 \%) \\
1 / 63(1.6 \%) \\
1 / 63(1.6 \%) \\
1 / 63(1.6 \%) \\
1 / 63(1.6 \%) \\
1 / 63(1.6 \%) \\
1 / 63(1.6 \%)\end{array}$ \\
\hline
\end{tabular}

\section{Discussion}

Our examination of 63 independent Ukrainian patients suffering from Gaucher disease identified a total of 32 pathogenic rearrangements: 22 one nucleotide substitutions, 2 of which were nonsense replacements, $2 \mathrm{du}-$ plications, 3 deletions, 1 splicing mutation and 4 recombinant rearrangements.

Replacement p.N409S is known to belong to so called "mild" variants of the gene and is almost not found in patients with neurological disorders [5]. In the group of Ukrainian patients replacement p.N409S was also found only in patients with type I GD - 41 of them

\begin{tabular}{|c|c|c|}
\hline 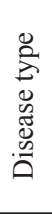 & Genotype & $\begin{array}{c}\text { Number of } \\
\text { genotypes/ } \\
\text { total number } \\
\text { of investigated } \\
\text { patients } \\
\text { (frequences) }\end{array}$ \\
\hline \multirow{12}{*}{ I } & p.L483P/p.R502C & $1 / 63(1.6 \%)$ \\
\hline & p.L483P/p.S390I & $1 / 63(1.6 \%)$ \\
\hline & del55/p.L483P+RecG & $1 / 63(1.6 \%)$ \\
\hline & p.F167L/p.Q453R & $1 / 63(1.6 \%)$ \\
\hline & p.G416S/p.G416S & $2 / 63(3.2 \%)$ \\
\hline & p.R202*/p.L483P+RecG & $1 / 63(1.6 \%)$ \\
\hline & p.R202*/p.G241R & $1 / 63(1.6 \%)$ \\
\hline & p.R87W/RecC5a & $1 / 63(1.6 \%)$ \\
\hline & p.R87W/c.901delC & $1 / 63(1.6 \%)$ \\
\hline & p.V414L/RecC & $1 / 63(1.6 \%)$ \\
\hline & p.L483P/RecNciI & $1 / 63(1.6 \%)$ \\
\hline & $\mathrm{RecG} / ?$ & $2 / 63(3.2 \%)$ \\
\hline \multirow{2}{*}{ II } & c.84dupG/p.P430A & $1 / 63(1.6 \%)$ \\
\hline & p.G241R/p.A423D & $1 / 63(1.6 \%)$ \\
\hline \multirow{4}{*}{ III } & p.D448H/[p.R159W+p.G241R] & $1 / 63(1.6 \%)$ \\
\hline & p.G416S/c.999G-A & $1 / 63(1.6 \%)$ \\
\hline & p.N227S/p.Y244* & $1 / 63(1.6 \%)$ \\
\hline & p.G416S/c203dupC & $1 / 63(1.6 \%)$ \\
\hline
\end{tabular}

carried this replacement in at least one allele, which amounted to $71.9 \%$ of all the patients with type I GD (Table 4). Moreover, the data, obtained by us, confirm the conclusions of other researchers on the mitigating impact of replacement p.N409S [6]. For instance, the availability of this replacement in patients 24 and 60 , regardless of the availability of zeromutation p.R202* in another allele, conditioned type I (non-neuronopathic) clinical course of medium severity (Table 2). Three patients, who had the identified recombinant alleles in the compound with replacement $p$. N409S which impairs the structure and func- 
tion of the $G B A$ gene considerably, underwent also a protective impact of the mentioned replacement, which conditioned the development of type I (non-neuronopathic) Gaucher disease.

Similar to most populations, replacement p.L483P was ranked the second most frequent among our patients $-14.5 \%(18 / 124)$ alleles contained this replacement as an individual mutation, and $5.6 \%$ more $(7 / 124)$ - as a constituent of recombinant alleles of distal regions of the $G B A$ gene. Traditionally, the replacement p.L483P is classified as "severe", it is often associated with the availability of neurological disorders in patients, especially in homozygous state [5]. No homozygote p.L483P/p.L483P was identified in the Ukrainian patients. 17 out of 18 carriers of replacement p.L483P, as an individual mutation, had type I (non-neuronopathic) Gaucher disease i.e. they had no neurological disorders. The severity of this replacement in 13 of them was mitigated by replacement p.N409S in the second allele, in two - by the presence of missense replacements p.I200S and p.R502C, also remarkable just for nonneuronopathic type of the disease [5]. One patient had replacement p.L483P, identified in the compound with RecC5a allele which was described predominantly for patients with type I Gaucher disease [5, 15].

Two homozygous carriers of replacement p.G416S were identified among the examined patients, both had type I (non-neuronopathic) Gaucher disease, which is in agreement with the data of other authors about "mild" nature of this replacement [20]. In two more patients, this variant was identified in the compound with another single nucleotide rearrangement one had cytosine duplication in exon 3 of the gene (c.203dupC) which conditions the shift in the reading frame, and another had the replacement of guanine for adenine in the last triplet of exon 7, which does not result in the amino acid replacement, but impairs the splicing site. Therefore, both rearrangements are "severe" by their phenotypic manifestation. It is noteworthy that there was no mitigating effect from "mild" replacement p.G416S on the impact of "severe" rearrangement in both patients who had type III (chronic neuronopathic) Gaucher disease (patients 50 and 57).

Replacement p.R159W is rather common for European populations and is usually characterized as "mild" by its phenotypic manifestation [5]. Among the Ukrainian patients this variant was identified in 5 patients with type I (non-neuronopathic) Gaucher disease in the compound with p.N409S and in one patient with type III chronic neuronopathic disease (patient 49) in the composition of a complex allele [p.R159W+p.G241R] and replacement p.D448H in the second allele.

While analyzing the phenotype of patients with identified recombinant alleles in the $G B A$ gene, it should be noted that genotype-phenotype correlation in them is ambiguous. On the one hand, it was predictable that all patients with genotype p.N409S/RecNciI would have type I (non-neuronopathic) Gaucher disease. A patient with genotype p.L483P/RecNciI (patient 13) was notable for early manifestation and severe clinical course of the disease, which conditioned the fatal outcome after a hemorrhage, resistant to treatment, at the age of four, regardless of conducted enzyme-replacement therapy. The absence of neurological symptoms in this patient at diagnostics was the reason why this case was classified as type I (non-neuronopathic) Gaucher disease. 
However, the "severity" of both mutations and early death allow for an assumption that there was no sufficient time for manifestation of the neurological symptoms in this patient], thus, this case may be considered to be type III (chronic neuronopathic) Gaucher disease.

Most described cases of the recombinant alleles, involving exons 5-7 of the $G B A$ gene ( $\mathrm{RecC}$ and RecC5a), were observed in the patients with no neurological disorders that was also demonstrated by us. It is notable the identification of genotype p.V414L/RecC in the patient with early severe clinical course of Gaucher disease without any neurological disorders but with hepatic gaucheroma and fatal outcome at the age of 6 (patient 51). Taking into consideration the published data about the clinical course in the patients, homozygous by the missense replacement $\mathrm{p} . \mathrm{V} 414 \mathrm{~L}$, this variant should be related to "mild" ones by its phenotypic manifestation [21]. Therefore, in combination with allele $\mathrm{RecC}$, which is also mainly observed in the patients with type I Gaucher disease, it could be expected that the patient 51 has either mild or medium degree of clinical course severity. Such contradiction requires detailed study to identify the genetic, epigenetic, and environmental factors, impacting the phenotypic manifestation of a specific genotype.

The results of genotyping other patients with neuronopathic types of Gaucher disease are in some agreement with the published data. Both mutations, identified in the patient 61 with type II acute neuronopathic disease (genotype p.G241R/p.A423D), described before, are remarkable for neuronopathic forms of Gaucher disease [22]. The duplication of guanine c.84dupG in exon 2 of the $G B A$ gene, identified in a patient with type II (acute neuronopathic) Gaucher disease, was also described as a "severe" form according to its phenotypic manifestation and is notable for neuronopathic forms of the disease. As seen from the published data, the phenotypic manifestation of missense replacement p.N227S depends on the rearrangement in the second allele. The combination of this variant with "mild" mutations, such as p.N409S, leads to the development of type I Gaucher disease, whereas the combination with "severe" mutations, such as Rec-alleles or p.L483P, leads to the occurrence of neuronopathic types of the disease [5]. Therefore, the nonsense replacement p.Y244*, identified in the compound with p.N227S in patient 54 , conditioned the development of type III (chronic neuronopathic) Gaucher disease.

The analysis in silico of new rearrangements in the GBA gene, described by us, demonstrated that nonsense replacement p.Y244* and missense replacement p.P430A might impair the structure and function of the gene product the most. The nonsense replacement p.Y244* is responsible for it due to the occurrence of a stop-codon in exon 6 and, as a result, the formation of a shortened gene product, which lost over half of amino acid residues and, first and foremost, the active site of the enzyme (E379) [23]. The effect of missense replacement p.P430A is due to the fact that amino acid residue $\mathrm{P} 430$ is localized in the loop, contacting with $\beta 8$-strand of the first domain TIM barrel in GBA molecule. This loop is localized on the upper surface of the active site and contacts the substrate molecule, which makes any replacements in this region critical for normal functioning of the 
active site of the enzyme [24]. Notably, in 1998 Cormand et al. described another replacement of proline $430-$ p.P430L in two patients with type I Gaucher disease [25]. However, in both patients this replacement was in the compound with p.N409S, which, taking into consideration the mitigating nature of this variant, made it impossible to evaluate the correlation of replacement p.P430L and the patients' phenotype. Replacement $\mathrm{p}$. P430A was identified by us in two patients - in the patient 26 with type I Gaucher disease, conditioned by the presence of replacement p.N409S in the second allele, and in the patient 31 with type II Gaucher disease, with the duplication c.84dupG in the second allele. The development of severe acute neuronopathic form of the disease in patient 31 (genotype p.P430A/c.84dupG) confirms that the replacement of proline 430 is a zero-mutation, conditioning a considerable loss in the enzymatic activity of glucocerebrosidase.

It is probable that missense replacement p.F167L might also impact the functional activity of $G B A$. Phenylalanine 167 is one of seven aromatic amino acids, forming a chain on one side of the active site pocket of a GBA molecule and is involved into the substrate recognition [27]. Leucine is not an aromatic amino acid, thus the replacement of phenylalanine with leucine leads to the impairment in the aromatic chain structure and therefore to the impairment of spatial organization of the active site pocket of the enzyme, which may have negative impact on the catalytic activity of glucocerebrosidase. Unfortunately, we were unable to evaluate phenotype-genotype association of this replacement because it was identified in the compound with "mild" replacement p.Q453R, which conditioned type I Gaucher disease in the patient 21.

Replacements p.N131I and p.S390I, described by us, influence amino acid residues, localized in domain III, the catalytic domain of GBA molecule, but do not participate directly in the recognition and binding of the substrate or activator of saposin C [23, 24]. This is the most likely factor, conditioning the "mild" impact of conformational changes in GBA molecule, caused by these replacements, on its catalytic activity. This is also confirmed by the clinical data of the patients, described by us, - replacement p.N131I in the compound with p.N409S led to the development of type I Gaucher disease with late manifestation (patient 43 , the first symptoms were identified at the age of 15), and replacement p.S390I mitigated the impact of "severe" replacement $p$. L483P in patient 5 and caused the development of type I Gaucher disease, albeit of medium severity with early manifestation (first symptoms at the age of 1 year), but without neurological disorders.

Therefore, the application of different molecular and genetic approaches, including direct gene sequencing, allowed us to identify $96.8 \%$ of mutant alleles in Ukrainian patients with Gaucher disease. Also six new and previously not described rearrangements of the $G B A$ gene sequence were identified. The comparison of genotypes with clinical form of the disease, identified in patients, demonstrated that at present there are recognized genotype-phenotype correlations for this disease, which allow predicting the type and clinical course of the disease to some degree. In most patients, described by us, the combination of genotype and phenotype corresponded to the data of 
numerous previous studies. The information about clinical signs of the disease in patients with new, previously not described mutations, allowed us to complement current information about genotype-phenotype correlations for Gaucher disease. However remarkably, there is considerable heterogeneity in the clinical course of the disease even among people with a similar genotype. This depends on different factors, influencing the realization of genetic information in a certain individual - the availability of complex alleles, the influence of adjacent or modifying genes, the impact of environmental factors, etc. These factors impact the possibilities of the clinical prognosis and require additional studies.

Therefore, the determination of molecular and genetic nature of a disease in a specific patient is the mandatory information, which allows confirming the diagnosis, predicting the clinical course of the disease and envisaging the response to specific therapy.

\section{REREFERCES:}

1. Lysosomal storage disorders: a practical guide. Eds: Mehta A, Winchester B. London: Wiley-Blackwell, 2012; 208 p.

2. Beutler E, Grabowski GA. Gaucher disease. In: The metabolic \& molecular bases of inherited diseases. Eds. Scriver CR, Beaudet AL, Sly WS, Valle D. New York: McGraw-Hill, 2009; 3668 p.

3. Horowitz M, Wilder S, Horowitz Z, Reiner O, Gelbart $T$, Beutler $E$. The human glucocerebrosidase gene and pseudogene: structure and evolution. $\mathrm{Ge}$ nomics. 1989;4(1):87-96.

4. Winfield SL, Tayebi N, Martin BM, Ginns EI, Sidransky $E$. Identification of three additional genes contiguous to the glucocerebrosidase locus on chromosome 1q21: implications for Gaucher disease. Genome Res. 1997;7(10):1020-6.
5. Hruska KS, LaMarca ME, Scott CR, Sidransky E. Gaucher disease: mutation and polymorphism spectrum in the glucocerebrosidase gene (GBA). Hum Mutat. 2008;29(5):567-83.

6. Beutler E, Gelbart T. Erroneous assignment of Gaucher disease genotype as a consequence of a complete gene deletion. Hum Mutat. 1994;4(3):212-6.

7. Koprivica V, Stone DL, Park JK, Callahan $M$, Frisch A, Cohen IJ, Tayebi N, Sidransky E. Analysis and classification of 304 mutant alleles in patients with type 1 and type 3 Gaucher disease. Am J Hum Genet. 2000;66(6):1777-86.

8. Hatton CE, Cooper A, Whitehouse C, Wraith JE. Mutation analysis in 46 British and Irish patients with Gaucher's disease. Arch Dis Child. 1997;77(1):17-22.

9. Germain DP, Puech JP, Caillaud C, Kahn A, Poenaru $L$. Exhaustive screening of the acid beta-glucosidase gene, by fluorescence-assisted mismatch analysis using universal primers: mutation profile and genotype/phenotype correlations in Gaucher disease. Am J Hum Genet. 1998;63(2):415-27.

10. Erdos M, Hodanova K, Taskó S, Palicz A, Stolnaja L, Dvorakova L, Hrebicek M, Maródi L. Genetic and clinical features of patients with Gaucher disease in Hungary. Blood Cells Mol Dis. 2007;39(1):119-23.

11. Malini E, Grossi S, Deganuto M, Rosano C, Parini R, Dominisini S, Cariati R, Zampieri S, Bembi B, Filocamo M, Dardis A. Functional analysis of 11 novel GBA alleles. Eur J Hum Genet. 2014;22(4): 511-6.

12. Alfonso P, Aznarez S, Giralt M, Pocovi M, Giraldo P; Spanish Gaucher's Disease Registry.. Mutation analysis and genotype/phenotype relationships of Gaucher disease patients in Spain. J Hum Genet. 2007;52(5):391-6.

13. Hodanová K, Hrebícek M, Cervenková M, Mrázová L, Vepreková L, Zemen J. Analysis of the beta-glucocerebrosidase gene in Czech and Slovak Gaucher patients: mutation profile and description of six novel mutant alleles. Blood Cells Mol Dis. 1999;25(5-6):287-98.

14. Mattošová S, Chandoga J, Hlavatá A, Saligová J, Maceková $D$. Spectrum of GBA mutations in patients with Gaucher disease from Slovakia: identification of five novel mutations. Isr Med Assoc J. 2015;17(3):166-70. 
15. Tylki-Szymañska A, Keddache M, Grabowski GA. Characterization of neuronopathic Gaucher disease among ethnic Poles. Genet Med. 2006;8(1):8-15.

16. Boukina TM, Tsvetkova IV. Distribution of mutations of acid b-d-glucosidase gene (GBA) among 68 russian patients with Gaucher's disease. Biochemistry (Moscow) Suppl Ser B: Biomed Chem. 2008;2(1): 105-10.

17. Horovenko NH, Ol'khovych NV, Nedoboü AM, Pichkur NO. [Detection of the frequencies of GBA gene major mutations in patients with Gaucher disease in Ukraine]. Tsitol Genet. 2007;41(4):41-7.

18. Miocić S, Filocamo M, Dominissini S, Montalvo AL, Vlahovicek K, Deganuto M, Mazzotti R, Cariati R, Bembi B. Pittis $M G$. Identification and functional characterization of five novel mutant alleles in 58 Italian patients with Gaucher disease type 1. Hum Mutat. 2005;25(1):100.

19. den Dunnen JT, Dalgleish R, Maglott DR, Hart RK, Greenblatt MS, McGowan-Jordan J, Roux AF, Smith T, Antonarakis SE, Taschner PE. HGVS Recommendations for the Description of Sequence Variants: 2016 Update. Hum Mutat. 2016;37(6):564-9.

20. Zimran A, Kay A, Gelbart T, Garver P, Thurston D, Saven A, Beutler E. Gaucher disease. Clinical, laboratory, radiologic, and genetic features of 53 patients. Medicine (Baltimore). 1992;71(6):337-53.

21. Amaral O, Marcão A, Sá Miranda M, Desnick RJ, Grace ME. Gaucher disease: expression and characterization of mild and severe acid beta-glucosidase mutations in Portuguese type 1 patients. Eur J Hum Genet. 2000;8(2):95-102.

22. Cormand B, Grinberg D, Gort L, Fiumara A, Barone $R$, Vilageliu L, Chabás A. Two new mild homozygous mutations in Gaucher disease patients: clinical signs and biochemical analyses. Am J Med Genet. 1997;70(4):437-43.

23. Stone DL, Tayebi N, Orvisky E, Stubblefield B, Madike V, Sidransky E. Glucocerebrosidase gene mutations in patients with type 2 Gaucher disease. Hum Mutat. 2000;15(2):181-8.

24. Dvir H, Harel M, McCarthy AA, Toker L, Silman I, Futerman AH, Sussman JL. X-ray structure of human acid-beta-glucosidase, the defective enzyme in Gaucher disease. EMBO Rep. 2003;4(7):704-9.
25. Atrian S, López-Viñas E, Gómez-Puertas P, Chabás A, Vilageliu L, Grinberg D. An evolutionary and structure-based docking model for glucocerebrosidase-saposin C and glucocerebrosidase-substrate interactions - relevance for Gaucher disease. Proteins. 2008;70(3):882-91.

26. Cormand B, Grinberg D, Gort L, Chabás A, Vilageliu L. Molecular analysis and clinical findings in the Spanish Gaucher disease population: putative haplotype of the N370S ancestral chromosome. Hum Mutat. 1998;11(4):295-305.

\section{Аналіз мутацій в гені $\boldsymbol{G B} A$ у пацієнтів 3 хворобою Гоше в Україні}

Н. В. Ольхович, А. М. Недобой, Н. О. Пічкур, Н. Г. Горовенко

Хвороба Гоше (МIM 230800) є найбільш поширеним захворюванням накопичення, яке спричинене спадковим дефіцитом лізосомного ферменту глюкоцереброзідази (ЕС 3.2.1.45). Ген глюкоцереброзідази (GBA) картований в локусі 1q21, його довжина 7,5 тис.п.н. і складається з 11 екзонів. За даними найбільших баз даних мутацій генів людини, існує більше 300 описаних в даний час патогенних варіантів гена $G B A$, більшість 3 них пов'язані 3 розвитком хвороби Гоше. Мета. Виявлення перебудов в гені $G B A$, які зумовили розвиток хвороби Гоше у хворих в Україні, порівняння їх частоти і спектру з варіантами у пацієнтів з інших європейських країн, а також оцінка генотип-фенотип асоціації для цього захворювання. Методи. Метод прямого автоматичного сиквенування за Сенгером на аналізаторі ABI 3130 (Applied Biosystems). Результати. Застосування різних молекулярних і генетичних підходів, включаючи пряме секвенування послідовності гена, дозволило нам ідентифікувати 96,8 \% мутантних алелів у українських пацієнтів 3 хворобою Гоше. Також були виявлені шість нових раніше не описаних перебудов послідовності гена $G B A$. Висновки. Порівняння виявлених у пацієнтів генотипів з клінічною формою захворювання показали, що отримані результати не суперечать сучасним визнаним генотипфенотип кореляціям, які дозволяють певною мірою прогнозувати тип і клінічний перебіг хвороби Гоше.

Кл юч о в і сл ов а: хвороба Гоше, ген $G B A$. 


\section{Анализ мутаций в гене $G B A$ у пациентов с болезнью Гоше в Украине}

\author{
Н. В. Ольхович, А. Н. Недобой, Н. А. Пичкур,
} Н. Г. Горовенко

Болезнь Гоше (МIM 230800) является наиболее распространенным заболеванием накопления, которое вызвано наследственным дефицитом лизосомного фермента глюкоцереброзидазы (ЕС 3.2.1.45). Ген глюкоцереброзидазы ( $G B A)$ картирован в локусе 1q21, его длина 7,5 тис.п.н. и состоит из 11 экзонов. По данным крупнейших баз данных мутаций генов человека, существует более 300 описанных в настоящее время патогенных вариантов гена $G B A$, большинство из них связаны с развитием болезни Гоше. Цель. Выявление перестроек в гене $G B A$, которые обусловили развитие болезни Гоше у больных в Украине, сравнение их частоты и спектра с вариантами у пациентов из других европейских стран, а также оценки генотип-фенотип ассоциации для это- го заболевания. Методы. Метод прямого автоматического сиквенирования по Сенгеру на анализаторе ABI 3130 (Applied Biosystems). Результаты. Применение различных молекулярных и генетических подходов, включая прямое секвенирование последовательности гена, позволило нам идентифицировать 96,8 \% мутантных аллелей у украинских пациентов с болезнью Гоше. Также были обнаружены шесть новых ранее не описанных перестроек последовательности гена $G B A$. Выводы. Сравнение выявленных у пациентов генотипов с клинической формой заболевания показали, что полученные результаты не противоречат современным признанным генотип-фенотипическим корреляциям, позволяющим в определенной степени прогнозировать тип и клиническое течение болезни Гоше.

Кл юч е вы е с лов а: болезнь Гоше, ген $G B A$.

Received 01.12.2016 